\title{
PELATIHAN GOOGLE APPS FOR EDUCATION KEPADA GURU MADRASAH ALIYAH (MA) TANBIHUL GHOFILIIN BANJARNEGARA
}

\author{
Sarmini ${ }^{1}$, Palupi Pandanarum ${ }^{1}$, Dinda Apriyatul Permanasari ${ }^{1)}$ \\ ${ }^{1)}$ Sistem Informasi, Fakultas IImu Komputer, Universitas Amikom Purwokerto, Jawa Tengah, Indonesia \\ Corresponding author : Sarmini \\ E-mail : sarmini@amikompurwokerto.ac.id
}

Diterima 10 Oktober 2020, Direvisi 26 Oktober 2020, Disetujui 27 Oktober 2020

\begin{abstract}
ABSTRAK
Mayoritas guru-guru MA di Tanbihul Ghofiliin telah menggunakan google namun belum semua guru mengetahui dan paham bagaimana memanfaatkan fasilitas google apps for education untuk mendukung kegiatan belajar mengajar. Solusi permasalahan yang ditawarkan kepada mitra adalah memberikan pelatihan penggunaan google classroom, form, meeting dan drive sebagai alternatif model pembelajaran baru yaitu pembelajaran kolaboratif non tatap muka (daring). Pelatihan ini bertujuan untuk meningkatkan kemampuan guru dalam kegiatan mengajar sehingga lebih menjadi profesional. Kegiatan Amikom Mitra Masyarakat pelatihan google aps for education kepada guru MA Tanbihul Ghofiliin dilaksanakan pada hari sabtu tanggal 8 Agustus 2020, kegiatan diawali dengan menjelaskan apa fungsi dari masing-masing aplikasi dan bagaimana cara penggunaannya. Kegiatan berikutnya melakukan praktik langsung bagaimana membuat kelas daring pada google classroom, membuat form pada google form dan pemanfaatan google drive sebagai penyimpanan awan dan diakhiri dengan diskusi/sesi tanya jawab dengan peserta. Hasil kegiatan menunjukan antusiasiame peserta yang cukup tinggi dengan kegiatan pelatihan yang diberikan dan diharapkan kedepannya akan ada pelatihan selanjutnya seperti pelatihan edit video untuk pembelajaran.
\end{abstract}

Kata kunci: pelatihan; guru; google; pembelajaran; daring.

\begin{abstract}
The majority of MA teachers in Tanbihul Ghofiliin have used Google, but not all teachers know and understand how to use Google Apps for Education facilities to support teaching and learning activities. The solution to the problems offered to partners is to provide training on the use of google classrooms, forms, meetings and drives as an alternative to new learning models, namely non-face-to-face (online) collaborative learning. This training aims to improve the ability of teachers in teaching activities so that they become more professional. Amikom Community Partners activities Google Aps for Education training for MA Tanbihul Ghofiliin teachers was held on Saturday, August 8, 2020, the activity begins by explaining what the function of each application is and how to use it. The next activity is to do hands-on practice on how to make online classes in google classroom, create forms on google forms and use google drive as cloud storage and ends with a discussion / question and answer session with participants. The results of the activity show that the participants' enthusiasm is quite high with the training activities provided and it is hoped that in the future there will be further training such as video editing training for learning.
\end{abstract}

Keywords: training; teacher; google; learning; online.

PENDAHULUAN

Seiring dengan terus berkembangnya teknologi dan pemanfaatannya di dalam segala aspek kehidupan tidak terkecuali dalam dunia pendidikan yang terus berkembang dan memanfaatkan teknologi guna mempermudah proses kegiatan belajar mengajar. Kompetensi profesional guru mutlak dikembangkan seiring dengan perkembangan teknologi dan informasi saat sekarang ini. Sebagai pembimbing dan mentor harus sigap menyikapi perubahan ini dengan turut mengembangkan diri dan selalu memperkaya pengetahuan serta informasi untuk menuntun murid kearah yang lebih baik(Buntoro, Ariyadi, \& Astuti, 2018).

Pergeseran paradigma dari pembelajaran pasif menjadi pembelajaran aktif melalui pembelajaran kolaboratif ini memberikan kesempatan kepada siswa untuk tumbuh dan berkembang sesuai dengan tingkat perkembangannya masing-masing. Pembelajaran kolaboratif tatap muka sendiri memiliki keterbatasan dalam hal waktu, dimana siswa tidak memiliki cukup waktu untuk 
memahami paparan yang disampaikan oleh siswa yang lain. Namun dalam pembelajaran kolaboratif non-tatap muka (daring), siswa memiliki kesempatan yang lebih banyak untuk memahami dan membangun pengetahuannya masing-masing. Diskusi daring yang merupakan bagian dari pembelajaran memiliki potensi untuk menumbuhkembangkan rasa keingintahuan siswa dan berpikir kritis (Maulana, 2018). Sehingga hal tersebut dapat memungkinkan para siswa untuk belajar dimana saja, kapan saja melalui perangkat mobile. Selain itu sikap kemandirian siswa dalam proses belajar dapat ditingkatkan dengan model pembelajaran daring (Malalina \& Yeni, 2018). Dan model pembelajaran yang bersifat inovatif ini dapat menciptakan pengalaman terbaik bagi guru dan siswa (Mayasari et al., 2019).

Google Apps for Education menjembatani kebutuhan siswa dan guru untuk berkolaborasi, berbagi dokumen, berdiskusi mengenai suatu materi belajar secara real-time, mengumpulkan tugas tanpa repot, dan banyak hal lainnya, sehingga baik siswa dan guru dapat belajar dengan efektif (Kurniawan, Purnomo, \& Idris, 2020). Google apps for education adalah layanan gratis dari google yang didedikasikan untuk dunia pendidikan dimana setiap orang dapat menggunakannya hanya dengan mendaftarkan diri ke akun google dan tidak diperlu memiliki website tersendiri (Leba \& Habeahan, 2020). Google memberi solusi untuk berkolaborasi dalam kegiatan pembelajaran dengan memanfaatkan layananlayanan google seperti Google Mail (Gmail), Google Drive (GDrive), Google Classroom, Google Calendar, Google Docs, Google Sheets, Google Slides, Google Forms, dan Google Sites (Hamdani, Suryadi, Harsanto, \& Broto, 2020).

Fasiltas yang disediakan google dapat digunakan untuk interaksi antara guru dengan murid, murid-murid, maupun sesama guru (Google, 2010). Google mail (Gmail) merupakan layanan surat elektronik (surel) yang disediakan google, layanan ini merupakan layanan yang paling banyak digunakan oleh pengguna surel di Indonesia (Post, 2017). Google drive merupakan fasilitas penyimpanan awan (cloud storage) google. Pengguna google drive belum sebanyak pengguna gmail, namun dari hasil riset Mc Kinsey menunjukkan bahwa terjadi kenaikan sebanyak $35 \%$ pengguna layanan penyimpanan awan dari tahun 2014 ke tahun 2015 (McKinsey \& Company, 2016).

Layanan tersebut saling bersinergi satu dengan lainnya untuk mempermudah para pengguna layanan google, lebih khusus lagi bagi guru untuk meningkatkan kualitas pembelajaran di dalam kelas. Oleh karena itu, penting bagi guru untuk menguasai berbagai layanan tersebut agar dapat menggunakan prinsip belajar secara mandiri, terstruktur, kreatif, produktif, dan inovatif (Saifullah \& Akbar, 2020). Selain itu, teknologi dapat menjadi sarana yang ampuh di tangan pengajar yang tahu cara menggunakannya.

Namun, pengajar di masa kini, khususnya yang mengajar di sekolah berpenghasilan rendah tidak selalu memiliki akses ke pelatihan yang dibutuhkan untuk membantu mereka mempelajari cara menggunakan teknologi tersebut dengan cara yang efektif dan bermanfaat. Maka dari itu perlu adanya pelatihan yang dilakukan untuk meningkatkan pengetahuan dan keterampilan kepada guru tentang bagaimana komunikasi efektif dapat dilakukan melalui media pembelajaran inovatif berbasis pembelajaran sehingga kualitas pengajaran dapat lebih baik (Mayasari et al., 2019)

MA Tanbihul Ghofiliin adalah salah satu lembaga pendidikan yang setingkat/setara dengan SMA/SMK yang ada di kabupaten Banjarnegara yang telah terfasiltasi oleh jaringan internet guna mendukung kelancaran dalam kegiatan belajar mengajar, pemanfaatan internet di MA Tanbihul Ghofiliin juga diharapkan dapat membantu dan mempermudah guru dalam menyelesaikan tugas dan tanggungjawabnya. Sebagian besar guru-guru di MA Tanbihul Ghofiliin merupakan guru muda yang aktif, enerjik, serta paham teknologi khususnya penggunaan internet dengan literasi internet yang baik. Dan mayoritas guru-guru MA di Tanbihul Ghofiliin telah menggunakan google, namun kebanyakkan hanya menggunakan google untuk sebatas melakukan pencarian di internet, berkirim surat elektronik menggunakan gmail maupun menerjemahkan kalimat atau dokumen dengan menggunakan google terjemahan. Tidak semua guru mengetahui dan paham bagaimana cara menggunakan fasilitas google apps for education. Pemanfaatan internet dalam proses pembelajaran daring yang dilakukan saat ini masih sebatas pencarian informasi saja dengan menggunakan bantuan internet.

Berdasarkan analisis situasi yang telah dipaparkan sebelumnya, maka untuk lebih mensosialisasikan optimalisasi pemanfaatan google di kalangan guru maka dilaksanakanlah suatu kegiatan pelatihan pemanfaatan Google Apps for Education kepada guru-guru MA Tanbihul Ghofiliin Banjarnegara. Pelatihan ini diharapkan dapat meningkatkan kemampuan guru dalam memanfaatkan google apps for education sebagai media pembelajaran daring 
serta menjadi sarana komunikasi efektif antara guru dan siswa dengan memanfaatkan berbagai fitur komunikasi yang ada pada aplikasi tersebut.

\section{METODE}

Metode pendekatan yang digunakan dalam kegiatan pelatihan google apps for education kepada guru-guru MA Tanbihul Ghofiliin dalam kegiatan Amikom Mitra Masyarakat ini meliputi penyampaian materi, praktik penggunaan google apps (google classroom, meeting, form dan drive) dan evaluasi kegiatan pelatihan. Kegiatan penyampaian materi dilakukan dengan menyampaikan materi secara teori tentang pengenalan dasar google apps. Metode praktikum adalah memandu para peserta untuk dapat mempraktikan langsung bagaimana menggunakan berbagai fitur yang ada pada google apps seperti google classroom, meeting, form dan drive. Sedangkan metode evaluasi berupa tanyajawab dengan peserta, hal ini bertujuan untuk mengetahui kendala/kesulitan peserta serta tingkat pemahaman yang diterima oleh peserta berkaitan dengan kegiatan pelatihan google apps for education kepada guru-guruMA Tanbihul Ghofiliin.

Pelaksanaan kegiatan pelatihan google apps for education kepada guru-guru MA Tanbihul Ghofiliin telah dilaksanakan pada hari Sabtu, tanggal 8 Agustus 2020 di ruang Laboratorium Komputer 2 MA Tanbihul Ghofiliin

Banjarnegara. Kegiatan pelatihan dimulai pada pukul $14.00-16.00$ WIB yang diikuti oleh 16 peserta yang merupakan bapak dan ibu guru pengajar di MA Tanbihul Ghofiliin

\section{HASIL DAN PEMBAHASAN}

Kegiatan pelatihan yang diberikan meliputi pelatihan penggunaan google classroom, meeting dan drive sedangkan untuk google form sendiri tidak diberikan dikarenakan bapak dan ibu guru di Tanbihul Ghofiliin sudah bisa menggunakannya. Dalam kegiatan pelatihan diawali dengan memberikan materi yang menjelaskan apa kegunaan dari masingmasing aplikasi tersebut dan kemudian dilanjutkan dengan praktik langsung oleh peserta dengan mengikuti panduan dari tim dosen yang membimbing kegiatan pelatihan. Praktik pertama yang dilakukan adalah membuat kelas pada google classroom, membuat forum diskusi di classroom dan juga membuat tugas kelas untuk siswa. Praktik berikutnya adalah para peserta diajarkan bagaimana cara menggunakan google meeting untuk kelas secara daring dan dilanjutkan dengan bagaimana menyimpan dan berbagi file melalui drive karena selama ini bapak dan ibu guru di MA Tanbihul Ghofiliin masih hanya memanfaatkan flashdisk untuk menyimpan file.

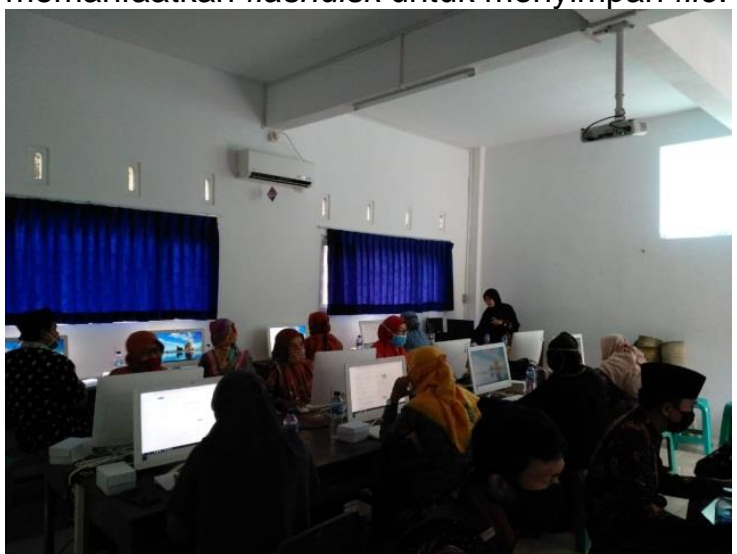

Gambar 1. Pemaparan materi

Pada gambar 1 Menunjukan kegiatan pemaparan materi secara singkat oleh salah satu pemateri dari tim pelatihan. Pada pemaparan materi dijelaskan oleh pemateri terkait apa fungsi dari beberapa aplikasi google apps seperti halnya penjelasan fungsi dari google classroom, form, dan drive.

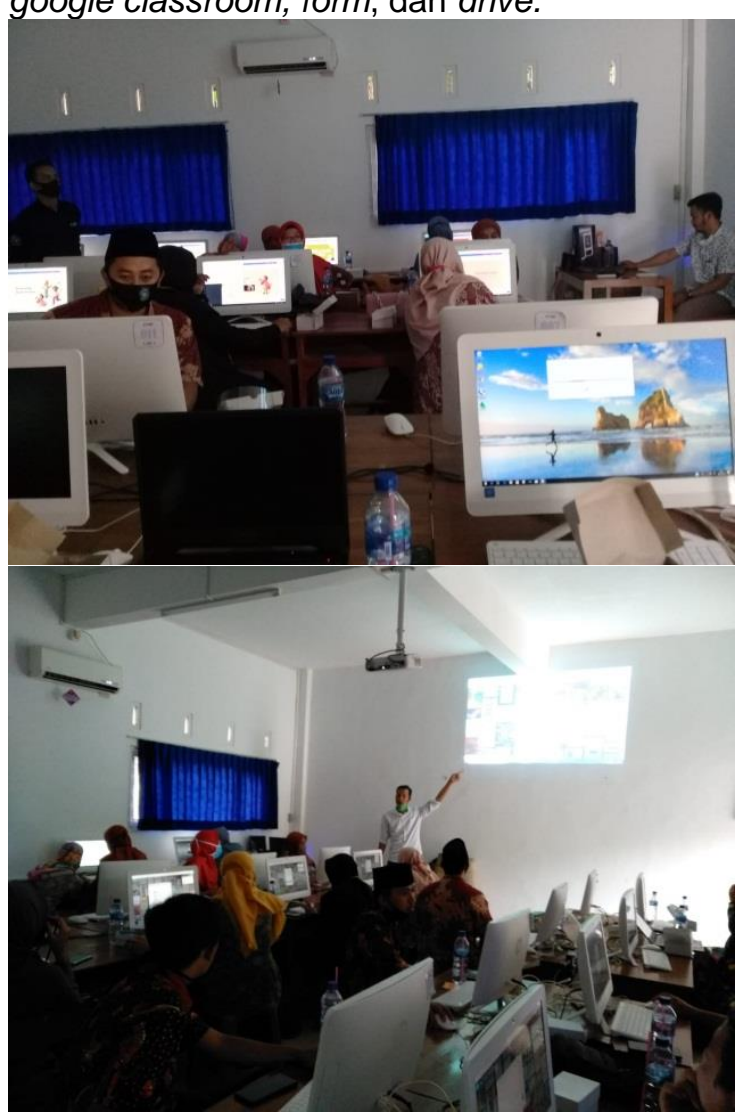

Gambar 2. Praktik langsung oleh peserta pelatihan

Gambar 2 diatas menunjukan kegiatan praktik langsung oleh para peserta yang dipandu oleh tim dosen bagaimana cara membuat dan menggunakan google apps seperti praktik bagaimana membuat kuisioner menggunakan google form, membuat kelas dan forum diskusi menggunakan google classroom dan juga 
menyimpan dan membagikan file secara penyimpanan awan dengan menggunakan google drive.

Kemudian pada pelatihan yang diberikan tim dosen juga memberikan materi tambahan berupa pelatihan untuk membuat materi pembelajaran yang menarik dengan menggunakan canva.com.

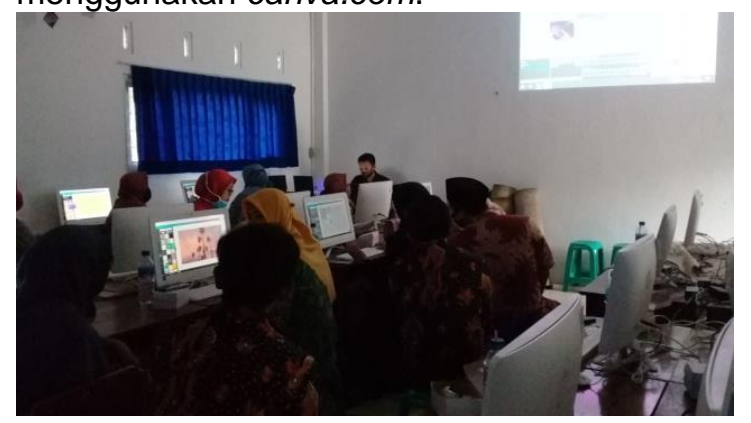

Gambar 3. Pemberian materi tambahan membuat materi pembelajaran yang menarik dengan menggunakan canva.com

Gambar 3 menjelaskan kegiatan tambahan materi yang diberikan oleh tim dosen yaitu dengan memberikan materi pelatihan bagaimana membuat materi pembelajaran yang menarik secara online dengan menggunakan canva.com. Pada sesi tambahan ini para peserta dipandu untuk mempraktekan secara langsung untuk membuat materi pembelajaran sesuai dengan mata pelajaran yang diampu oleh masing-masing bapak dan ibu guru. Peserta dipandu dari awal bagaimana membuka aplikasi canva.com kemudian melakukan login dan membuat lembar kerja baru. Setelah itu peserta juga diajarkan bagaimana menambahkan video dan menyisipkan gambar dan juga mengunduh materi yang telah dibuat.

Pada akhir kegiatan pelatihan diberikan waktu bagi peserta untuk mengajukan pertanyaan terkait dengan pelatihan yang telah diberikan, dalam sesi tanyajawab tersebut ada beberapa pertanyaan yang diberikan oleh peserta seperti bagaimana cara memasukan video kedalam forum diskusi di kelas kemudian juga berkaitan dengan bagaimana cara membagikan file presentasi didalam pertemuan daring menggunakan google class meeting. Selain itu juga ada pertanyaan bagaimana cara membuat tampilan presentasi yang menarik dan membuat video pembelajaran yang menarik. Dari seluruh rangkaian kegiatan pelatihan yang dilakukan peserta sangat antusias dalam mengikuti kegiatan pelatihan dan merekapun sangat dengan baik dapat mengikuti dan mempraktikan secara langsung apa yang diarahkan oleh tim dosen dalam memberikan pelatihan.
Berdasarkan hasil pengamatan dan tanya jawab yang dilakukan selama kegiatan berlangsung, kegiatan pelatihan google apps for education kepada guru-guru MA Tanbihul Ghofiliin memberikan hasil sebagai berikut:

a. Meningkatnya pengetahuan peserta mengenai pemanfaatan google apps for education untuk mendukung kegiatan pembelajaran daring.

b. Peserta dapat memahami, mengikuti dan mempraktik secara langsung dengan baik penggunaan google classroom, meeting, form dan drive sebagai media pembelajaran daring.

c. Pelatihan google apps for education kepada guru-guru MA Tanbihul Ghofiliin dapat meningkatkan kemampuan guru dalam memanfaatkan teknologi khususnya google apps for education untuk kegiatan proses belajar mengajar dalam masa pandemik.

d. Kegiatan ini dihadiri oleh 16 peserta. Tanggapan dari peserta pelatihan sangat positif karena peserta merasakan manfaat dari kegiatan Amikom Mitra Masyarakat yaitu pelatihan google apps for education kepada guru-guru MA Tanbihul Ghofiliin. Peserta dapat menerima dan memahami dengan baik materi pelatihan yang diberikan dan mengikuti praktik penggunaan aplikasi dengan baik pula.

e. Peserta antusias untuk dapat diberikan pelatihan membuat presentasi materi pembelajaran yang menarik dan editing video pembelajaran.

\section{SIMPULAN DAN SARAN}

Kegiatan Amikom Mitra Masyarakat pelatihan google apps for education kepada guru-guru MA Tanbihul Ghofiliin dapat berjalan dengan baik dan memperoleh respon/tanggapan yang positif dari peserta kegiatan. Kegiatan pelatihan ini dihadiri oleh 16 peserta. Tanggapan terkait kegiatan ini sangat positif karena peserta merasakan manfaat dan dampak positif dari kegiatan pelatihan ini yaitu meningkatnya pengetahuan bapak dan ibu guru di MA Tanbihul Ghofiliin dalam memanfaatkan aplikasi-aplikasi pada google untuk mendukung proses kegiatan belajar mengajar secara daring di masa pandemik.

Dan saran yang disampaikan oleh mitra dan peserta pada kegiatan Amikom Mitra Masyarakat berikutnya adalah ada kegiatan pelatihan lanjut tentang bagaimana membuat materi dan video pembelajaran yang menarik untuk siswa.

\section{UCAPAN TERIMAKASIH}

Terima kasih kepada Universitas Amikom 
Purwokerto terutama Lembaga Penelitian dan Pengabdian kepada Masyarakat, serta MA Tanbihul Ghofiliin Banjarnegara yang telah membantu secara moril maupun materiil dalam pelaksanaan kegiatan Pengabdian Kepada Masyarakat ini.

\section{DAFTAR RUJUKAN}

Buntoro, G. A., Ariyadi, D., \& Astuti, I. P. (2018). Pemanfaatan E-Learning Quipper School oleh Guru dan Siswa untuk Optimalisasi Pembelajaran di MAN 1 Ponorogo. Jurnal Pengabdian Kepada Masyarakat (Indonesian Journal of Community Engagement), Vol. 3, pp. 153-160. https://doi.org/10.22146/jpkm.27404

Google. (2010). Professional development handbook. Mountain View: Google.

Hamdani, A. U., Suryadi, L., Harsanto, K., \& Broto, S. (2020). PELATIHAN PENGGUNAAN GOOGLE CLASS ROOM UNTUK MENUNJANG KEGIATAN BELAJAR BAGI GURU SMK MUHAMMADIYAH 9 JAKARTA. IKRAITH-ABDIMAS, 3(1), 95-100.

Kurniawan, B., Purnomo, A., \& Idris. (2020). Pelatihan Penggunaan Aplikasi Google Classroom Sebagai Upaya Peningkatan Pembelajaran Online. International Journal of Community Service Learning, 4(1), 1-9. https://doi.org/10.23887/ijcsl.v4i1.2223 6

Leba, S. M. R., \& Habeahan, N. L. S. (2020). PELATIHAN MODEL PEMBELAJARAN JARAK JAUH MEDIA PEMBELAJARAN Universitas Musamus merauke KOMMAS: Jurnal Pengabdian Kepada Masyarakat Universitas Pamulang. KOMMAS, 1(2), 42-46.

Malalina, \& Yeni, R. F. (2018). Pelatihan Google Classroom untuk Mengoptimalisasi Proses Pembelajaran di FKIP Univeristas Tamansiswa Palembang. Jurnal Cemerlang, 1(1), 58-70.

Maulana, D. A. (2018). Pelatihan Pemanfaatan Google Apps for Education Bagi Guru Guru di MGMP Matematika SMA Kabupaten dan Kota Kediri. 1390-1396.

Mayasari, F., Dwita, D., Jupendri, Jayus, Nazhifah, Hanafi, K., \& Putra, N. M. (2019). PELATIHAN KOMUNIKASI EFEKTIF MEDIA PEMBELAJARAN GOOGLE CLASSROOM BAGI GURU MAN 2 MODEL PEKANBARU. Jurnal Pengabdian Untuk Mu NegeRI, 3(1), 18-23.
McKinsey, \& Company. (2016). Unlocking Indonesia's Digital Opportunity. Jakarta.

Post, G. (2017). elQ Data: Gmail is the Most Used Email Service in Indonesia.

Saifullah, S., \& Akbar, B. M. (2020). PELATIHAN

E-LEARNING

MENGGUNAKAN GOOGLE CLASSROOM BAGI GURU MA RADEN FATAH PRAMBANAN. GERVASI, 4(1), 93-103. 